\title{
AGREEMENT ON THE ORGANIZATION FOR INDIAN OCEAN MARINE AFFAIRS CO-OPERATION (IOMAC)
}

Arusha, 7 September 1990

$\mathbf{I}$

\section{DEFINITIONS}

Article 1

Definitions

For the purposes of this Agreement:

"coastal State of the Indian Ocean" means a State the coast of which borders on, or is contained within, the Indian Ocean or the adjacent seas or gulfs thereof;

"hinterland State" means a State which is immediately adjacent to a coastal State of the Indian Ocean;

"land-locked State" shall have the same meaning as in the United Nations Convention on the Law of the Sea;

"geographically disadvantaged State" shall have the same meaning as in the United Nations Convention on the Law of the Sea;

"active in marine affairs in the Indian Ocean" means having substantial marine affairs activities in the Indian Ocean or its adjacent seas or gulfs.

II

\section{GENERAL PROVISIONS}

Article 2

\section{Establishment}

1. The Organization for Indian Ocean Marine Affairs Co-operation (IOMAC) hereinafter referred to as the "Organization" is hereby established.

2. The headquarters of the Organization shall be in Colombo, Sri Lanka.

379

Ko Swan Sik et al. (eds.), Asian Yearbook of International Law, 379-388.

(C) 1993 Kluwer Academic Publishers. Printed in the Netherlands. 


\section{Article 3}

\section{Objectives}

The objectives of the Organization shall be:

(a) To create an awareness regardness the Indian Ocean, its resources and potential for the development of the States of the region, and promoting co-operation among them, as well as between them and other States, bearing in mind the ocean régime embodied in the United Nations Convention on the Law of the Sea;

(b) To provide a forum where the coastal and hinterland States of the Indian Ocean and other interested States could consider, examine and review the economic uses of the Indian Ocean, its resources and related activities including those undertaken within the framework of intergovernmental organizations, and to identify fields in which they could benefit from enhanced international co-operation, co-ordination and concerted action;

(c) To enhance the economic and social development of the coastal and hinterland States of the Indian Ocean through integration of ocean-related activities in their respective development processes, and to further a policy of integrated ocean management through regular and continuing dialogue and co-operative international and regional action with particular emphasis on technical co-operation among developing countries.

\section{Article 4}

\section{Principles and fields of co-operation}

1. Principles of co-operation in marine affairs in the Indian Ocean shall be:

(a) optimization of the utilization of the resources of the Indian Ocean for the benefit of the States of the Indian Ocean;

(b) development of national capabilities in marine affairs with a view to promoting self-reliance in ocean management;

(c) enhancement of co-operation with other States;

(d) establishment and maintenance of effective co-operation with international, governmental, and nongovernmental organizations. agencies and other entities active in marine affairs; and

(e) due regard to the rights and needs of the land-locked and geographically disadvantaged Member States recognized in the new ocean régime.

2. Fields of co-operation in marine affairs in the Indian Ocean shall be:
(a) marine science, ocean services and marine technology;
(b) living resources;
(c) non-living resources; 
(d) ocean law, policy and management;

(e) marine transport and communications;

(f) marine environment; and

(g) other fields relevant to co-operation in marine affairs.

III

\section{INSTITUTIONAL PROVISIONS}

Article 5

\section{Membership}

Any coastal or hinterland State of the Indian Ocean may become a Member of the Organization by becoming a party to this Agreement.

\section{Article 6}

\section{Structure of the Organization}

The Organization shall have the following principal bodies:
(a) the Conference;
(b) the Committee; and
(c) the Secretariat.

\section{Article 7}

The Conference

\section{Composition}

1. The Conference shall be composed of representatives at a ministerial or equivalent level of all the Members of the Organization.

\section{Functions}

2. The Conference shall:

(a) establish policies and principles which shall govern the programmes and activities of the Organization;

(b) elect the members of the Committee of the Organization in accordance with the provisions of article 8, paragraph 1, below;

(c) appoint the Secretary-General of the Organization; 
(d) receive and consider the reports of the Committee and of the SecretaryGeneral;

(e) approve the budget and accounts of the Organization for each financial period;

(f) approve proposals for programmes and activities of the Organization;

(g) establish such subsidiary bodies as it may deem necessary;

(h) examine disputes that may arise concerning the interpretation or application of this Agreement and make such recommendations, and if necessary establish such procedures as it may deem appropriate with a view to their solution;

(i) establish its rules of procedure except as otherwise provided in this Agreement;

(j) establish the financial regulations of the Organization;

(k) establish the staff regulations of the Organization and provide for conditions of service consistent as far as possible with those of other international organizations;

(l) exercise such other functions as may be permissible under this Agreement.

\section{Meetings and procedure}

3. The Conference shall meet in regular session once every two years.

4. The Conference shall meet in special session whenever a majority of its Members of the Committee requests the convening of a special session.

5. A quorum for meetings of the Conference shall be two-thirds of the Members of the Organization.

6. Each Member shall have one vote.

7. The Conference shall endeavour to reach its decisions by consensus. Where consensus is not possible, decisions of the Conference shall unless otherwise provided in this Agreement be made by a majority of the Members present and voting.

8. The Conference shall at each regular session elect from amongst the Members its President and Vice-Presidents. They shall hold office until the election of their successors at the next regular session of the Conference.

9. Representatives of Governments not Members of the Organization, representatives of the United Nations and the appropriate agencies and bodies of the United Nations, representatives of such other international and national governmental or non-governmental organizations as the Conference may deem appropriate, and experts in fields of interest to the Conference may be invited to attend meetings of the Conference as observers. If one third of the Members of the Organization objects to the invitation of an observer to the Conference that observer shall not be invited thereafter.

10. Sessions of the Conference shall be held at the headquarters of the Organization unless the Conference decides otherwise. 
Article 8

The Committee

\section{Composition}

1. The Conference shall determine the size and elect the members of the Committee from amongst the Members of the Organization, and shall endeavour to ensure that the major geographical areas and the principal ocean-related interests (namely, landlocked, geographically disadvantaged, mainland, coastal and archipelagic) shall be represented in the Committee.

\section{Functions}

2. The Committee which shall be the executive body of the Organization shall:

(a) provide the necessary policy guidance for the implementation of the Programme of Co-operation and Plan of Action of the Organization, and for the furthering of co-operation through the framework of the Organization;

(b) consider the implementation of decisions taken by the Conference;

(c) supervise the administration and finances of the Organization;

(d) submit to the Conference, for its approval, the budget estimates and accounts of the Organization, together with comments and recommendations;

(e) submit to the Conference, for its approval, proposals for programmes and activities of the Organization;

(f) authorize the Secretary-General to take whatever steps the Committee considers necessary for achieving the objectives of the Organization;

(g) establish its rules of procedure except as otherwise provided in this Agreement; and

(h) exercise such other functions as may be referred to it by the Conference.

\section{Meetings and procedure}

3. The Committee shall meet in regular session once a year.

4. The Committee shall meet in special session whenever a majority of the members of the Committee requests the convening of a special session.

5. A quorum for meetings of the Committee shall be two thirds of the members of the Committee.

6. The Committee shall elect a Chairman and a Vice-Chairman.

7. Members of the Organization not elected to the Committee may participate at its meeting without a vote.

8. The Committee shall endeavour to reach its decisions by consensus. Where consensus is not possible, decisions of the Committee shall, unless otherwise provided in this Agreement, be made by a majority of its members present and voting. 
9. Representatives of Governments not Members of the Organization, representatives of the United Nations and the appropriate agencies and bodies of the United Nations, representatives of such other international and national governmental and non-governmental organizations as the Committee may deem appropriate, and experts in fields of interest to the Committee may be invited to attend meetings of the Committee as observers. If one third of the Members of the Organization objects to the invitation of an observer to the Committee that observer shall not be invited thereafter.

\section{Article 9}

\section{The Secretariat}

1. The Secretariat shall be composed of the Secretary-General, who shall be the chief administrative officer of the Organization, and such staff as the Organization may require.

2. The Secretary-General shall be appointed by the Conference for a period of four years on such terms as the Conference shall determine, and shall be eligible for reappointments.

3. The Secretary-General shall as chief administrative officer, be responsible under the guidance of the Committee for the administration of the Organization and its programmes. He shall ensure that the Organization shall be an effective and dynamic channel of co-operation in marine affairs in the Indian Ocean.

4. The Secretary-General shall:

(a) serve as Secretary of the Conference and of the Committee;

(b) report to the Conference and to the Committee on the administration of the programmes and activities of the Organization;

(c) report to the Conference and the Committee on the financial and other resources available to the Organization;

(d) having regard to the importance of ensuring efficiency and equitable geographical representation, appoint such staff as may be necessary for the proper functioning of the Secretariat;

(e) prepare and submit to the Committee the budget estimates and accounts of the Organization, and proposals for programmes and activities for the consideration of the Committee;

(f) perform such other tasks as may be entrusted to him by the Conference or the Committee.

5. The Secretary-General shall be responsible to the Conference in the performance of his functions. 
Article 10

Legal status

The Organization shall have juridical personality and the capacity necessary for the performance of its functions and, in particular, to contract, to acquire and dispose of movable and immovable property and to institute legal proceedings.

\section{Article 11}

\section{Facilities, privileges and immunities}

1. Each Member of the Organization shall accord to the Organization, its representatives, officials and consultants such facilities, privileges and immunities as it accords to intergovernmental organizations of a similar nature.

2. The Organization shall conclude a headquarters agreement with the Government of Sri Lanka. Until such time as a headquarters agreement is concluded, the Government of Sri Lanka shall accord to the Organization, its representatives, officials and consultants such facilities, privileges and immunities as it accords to intergovernmental organizations of a similar nature.

\section{Article 12}

\section{Relations with other organizations}

The Organization shall establish effective relations and co-operate closely with the United Nations and the appropriate agencies and bodies of the United Nations, as well as with other governmental and non-governmental organizations, agencies and institutes that are active in marine affairs.

IV

\section{RESOURCES}

Article 13

\section{Resources}

1. The resources of the Organization shall include:

(a) the financial contributions of the Members of the Organization in accordance with paragraph 2 of this article;

(b) such additional financial contributions as Members may wish to make to ensure that the programmes and activities of the Organization proceed on a sound financial basis;

(c) other funds whose receipt is consistent with the purposes of the Organization as determined by the Secretary-General in consultation where necessary with the Committee; 
(d) contributions of a non-financial nature whose receipt is consistent with the purposes of the Organization as determined by the Secretary-General in consultation where necessary with the Committee.

2. The financial contributions of the Members of the Organization shall consist of a yearly contribution from each Member, made in United States dollars, as follows:

(a) a sum arrived at by dividing 50 per cent of the required and approved budget of the Organization equally amongst all the Members of the Organization; and

(b) an additional sum, the amount of which shall be determined periodically by the Secretariat and approved by the Committee, to meet its share of the remainder of the required and approved budget. Such amount shall be calculated on the basis of the rates of assessment applicable in the United Nations, to the Members of the Organization with respect to their contributions to the regular budget of the United Nations.

Provided that the contributions, under sub-paragraphs (a) and (b) above, of any Member of the Organization shall not in the aggregate exceed $\$ 30,000$ a year for the first financial period of the Organization and, thereafter, such fixed annual sum for each subsequent financial period as the Conference shall determine.

3. A Member which is in arrears in the payment of its contributions under paragraph 2 above to the budget of the Organization to the extent that the amount of its arrears is equivalent to or exceeds the sum of its required contributions, under paragraph 2 above, for the two preceding calendar years, shall cease to be entitled to vote in the Conference and to be represented in the Committee. The Conference may nevertheless permit such a Member to vote if it is satisfied that the failure to pay is due to conditions beyond the control of the Member.

\section{Article 14}

\section{Management of resources}

1. The Conference and the Committee shall at each of its sessions review the status of the resources of the Organization and shall make such recommendations to the Members of the Organization, as may be deemed appropriate, to ensure that timely and adequate resources are always available to the Organization and its programmes, and that a reasonable balance between such resources and the programmes and activities of the Organization is maintained.

2. The resources of the Organization shall be administered on a sound economic and financial basis.

3. Rules for the receipt, custody and expenditure of the financial and non-financial resources of the Organization and for the auditing of its accounts shall be established by the Secretary-General with the approval of the Committee. 


\section{FINAL PROVISIONS}

Article 15

Signature, ratification, accession

1. Any coastal or hinterland State of the Indian Ocean may become a party to this Agreement by:

(a) signing this Agreement subject to ratification, acceptance or approval, and, thereafter, depositing an instrument of ratification, acceptance or approval; or

(b) acceding to this Agreement.

2. This Agreement shall be open for signature at the Ministry of Foreign Affairs, Dar es Salaam, United Republic of Tanzania and at the secretariat of the Organization for Indian Ocean Marine Affairs Co-operation, in Colombo, Sri Lanka, until its entry into force.

3. Instruments of ratification, acceptance, approval or accession shall be deposited with the Government of Sri Lanka.

Article 16

Entry into force

1. This Agreement shall enter into force on the thirtieth day after eight States have become parties to this Agreement in accordance with article 15.

2. For each State depositing an instrument of ratification, acceptance, approval or accession after the entry into force of this Agreement, the Agreement shall enter into force on the thirtieth day after such deposit.

\section{Article 17}

\section{Amendment}

1. Any party to this Agreement may propose an amendment to this Agreement.

2. The text of the proposed amendment shall be communicated by the Secretary-General to all the parties to this Agreement at least six months in advance of consideration of the proposed amendment by the Conference.

3. If approved by a two-thirds majority in the Conference, the proposed amendment shall, nevertheless, only enter into force for all parties to this Agreement on the thirtieth day after deposit of instruments of acceptance or approval of the proposed amendment by two thirds of the parties to this Agreement. 
Article 18

\section{Withdrawal from the Organization}

1. Any Member of the Organization may withdraw from this Agreement and, in doing so, from its Membership in the Organization by giving written notice of withdrawal to the depositary of this Agreement and to the Secretary-General.

2. The withdrawal shall take effect six months after the date of receipt of the notification by the depositary.

3. A Member withdrawing from the Organization shall continue to be responsible for the obligations incurred within the period of its membership.

Article 19

\section{Dissolution of the Organization}

1. The Conference may, by a two-thirds majority of its Members, resolve that the Organization shall be dissolved.

2. On the endorsement of such a resolution by two thirds of the States parties to this Agreement in notifications addressed to the President of the Conference the necessary steps shall be taken by the Conference for the dissolution of the Organization. These steps shall include the establishment by the Conference of a committee to advise the Conference, in consultation with the Committee and the Secretary-General, on the manner in which the assets and obligations of the Organization should be liquidated prior to its dissolution.

3. The Conference shall, at the appropriate stage, adopt a final declaration stating that on a specified date the Organization shall be deemed dissolved. The declaration shall be communicated by the President of the Conference to the Members of the Organization and to the depositary of this Agreement.

\section{Article 20}

\section{Depositary}

The two original copies of this Agreement shall be deposited with the Government of Sri Lanka which will be the depositary of this Agreement in accordance with the Vienna Convention on the Law of Treaties.

IN WITNESS WHEREOF the undersigned, being duly authorized thereto by their respective Governments, have signed this Agreement.

DONE at Arusha, the United Republic of Tanzania, in two copies in the English language this seventh day of September one thousand nine hundred and ninety. 